\title{
Chapter 12 \\ Migration from Central and Eastern Europe to Turkey
}

\author{
Deniz Karcı Korfalı and Tuğba Acar
}

\subsection{Introduction}

Until recently, despite the fact that the country had received many immigrants since the initial years of the Republic, migration literature treated Turkey as a country of emigration. Turkey's position in the international migration system, and thus, in the migration literature, has changed only recently to a country of transit and immigration. In this regard, the literature on international migration in Turkey is still very limited and either focused on mobility of specific groups, ${ }^{1}$ or on general historical trends. ${ }^{2}$ In this frame, focusing on current trends and implications of Central and Eastern European (CEE) migration in Turkey is a novel task. However, as the collection and distribution of international migration data have been generally neglected and a large portion of international migration in Turkey is on irregular basis, this is a challenging task. In addition to the limited data availability, the heavy internal and external migrant population also complicates migration research and blurs the distinction between the implications of CEE migration and migration in general.

The analysis of the newly established corridors between CEE and Turkey, the current migrant categories and finally, the implications of CEE migration require an overview of the background on CEE migration to Turkey. ${ }^{3}$ Following a historical background, this chapter will first assess the regular CEE migration by employing residence and work permit data along with citizenship statistics. In this respect,

\footnotetext{
${ }^{1}$ See for example, Danış on Iraqi, 2007, Parla on Bulgarian, 2007, or Eder on Moldovan (2007) migrations

${ }^{2}$ See for example, İçduygu and Kirişci, 2009

${ }^{3}$ In this study, CEE is perceived as a geographical region that includes Bulgaria, Croatia, Czech Republic, Estonia, Hungary, Latvia, Lithuania, Poland, Romania, Slovakia and Slovenia, Albania, Belarus, Bosnia Herzegovina, Kosovo, Macedonia, Moldova, Montenegro, Serbia and Ukraine.

D. K. Korfalı $(\bowtie) \cdot$ T. Acar

Özyeğin University, Oyzegin, Turkey

e-mail: dkorfali@ku.edu.tr
} 
the limited data still brings to light the corridors of permanent, student and labor migration established between CEE countries and Turkey in addition to patterns of gender and education. Next, irregular CEE migration will be addressed. This will be followed by region-specific focus on Edirne, which has traditionally received CEE migrants and Istanbul, Turkey's migration hub that includes various types of migrants from across the world. ${ }^{4}$ These two research areas reveal how different CEE migrant profiles lead to different implications of CEE migration. The final conclusion and discussion will shed light on the challenges of migration governance during Turkey's transformation to a migrant receiving country.

Within this framework, it should also be noted that the Turkish case can be received as a reference case. Unlike Austria, Netherlands and Sweden, here, CEE migrants are subject to the general terms for migrants in Turkey within an immigration regime established distinct from regulations on CEE migration applied by the EU members.

\subsection{Background on CEE Migration into Turkey}

Among the migration trends of the Early Republican Period, the course of CEE migration into Turkey, usually categorized as Balkan migrations, was the widest one and formed of four origin countries of the time: Bulgaria, Greece, Romania and Yugoslavia (Please see Chart 12.1). The Republic of Turkey, in need of human capital for a homogenous nation state, welcomed migrants of Sunni-Islam origin rather than Turkish ethnicity (Kirişci 2006). In 1935, out of an approximate population of 16 million citizens in Turkey, approximately 110,000 people were of CEE origin including Pomaks, Bosnians, Albanians, Bulgarians and Romanians (Çağatay 2007).

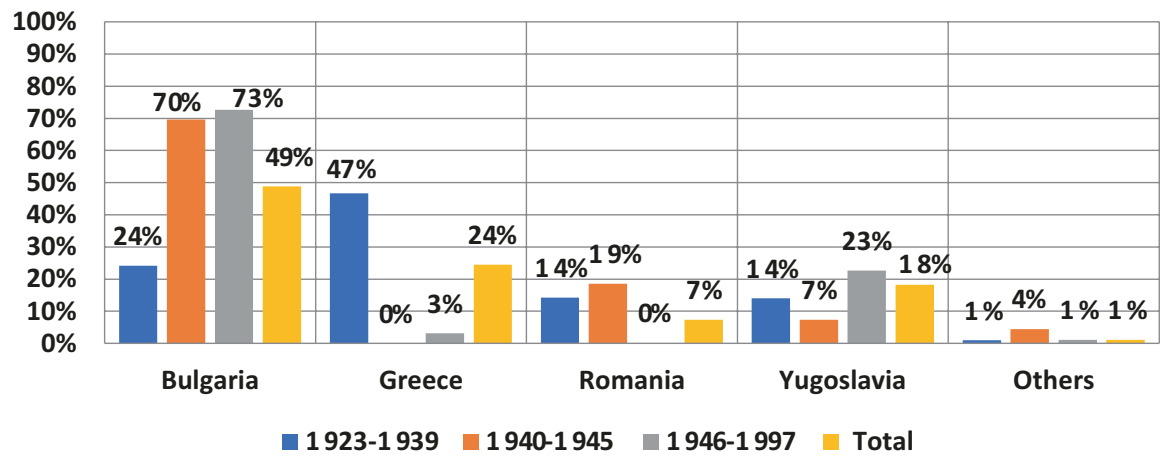

Chart 12.1 Immigration from Central and Eastern Europe to Turkey (1923 to 1997)

${ }^{4}$ These will be explained in further detail in the sections below. 
According to the 1960 Census, Pomaks, Bosnians and Albanians formed the $2 \%$ of Turkey's population (Dündar 1999).

In the period following the foundation of the Republic of Turkey in 1923 until the start of the Second World War, more than 800,000 people migrated to Turkey from the Balkans. Close to half of the total migrant population constituted of Greek migrants (47 percent) followed by Bulgarian ( 24 percent), Romanian (14 percent) and Yugoslavian migrants (13 percent). Migration from the Balkans declined in the war years and remained limited to approximately 20,000 migrants most of whom were Bulgarians (70 percent) and in much smaller numbers, Romanians (19 percent). During the Cold War, Turkey welcomed a massive wave of 600,000 ethnically Turkish Bulgarians due to Bulgaria's negative policies against its minorities coupled with a population of 200,000 Yugoslavian migrants. In spite of this rich variety of movements across the border, Bulgarians' mass migration based on ethnic kin is the most studied pattern of CEE migration in Turkey. ${ }^{5}$

In the current period, ethnic kin migration and migration to find a safe haven from repressive communist regimes are replaced by various types of CEE migration. Turkey's neo-liberal economic policies after the year 1990 and the growing economy resulted in more diverse migration flows from this region to Turkey. Today, five main movements of CEE migration into Turkey are (1) high skilled migration of professionals, (2) low skilled migration of domestic workers -with both regular and irregular status, (3) marriage migration, (4) increasing numbers of student migration and finally, (5) trafficked persons -albeit the official numbers from CEE seem to be decreasing. Along with the already existing migration flows from Bulgaria, Romania and ex-Yugoslavian countries, wider migration corridors from countries like Moldova and Poland started becoming significant. Lastly, although the numbers of migrants from Baltic Countries are relatively smaller, in the last decade migrants from Estonia, Lithuania and Latvia increased four-fold, six-fold and ten-fold respectively. Based on the official data, these current trends of CEE migration can best be analyzed in two main categories of regular versus irregular migration.

\subsubsection{Regular CEE Migration into Turkey}

Official statistics on current and regular migrants in Turkey are based on residence permits and citizenship acquisition. Traditionally, CEE migrants have a large weight in the number of total regular migrants in Turkey. The data from the Ministry of Interior demonstrates that in the years from 2003 to 2007, around an average of 40 percent of all regular migrants came from this region (Please see Chart 12.2). In the year 2008, however, the CEE migrant population in Turkey dropped to 26 percent. Consequently, except a small uptrend in 2011 right after the Eurozone Crisis, the weight of regular CEE migrants is in a steady decline. The main reasons behind this

${ }^{5}$ See Parla 2003, 2006 
Chart 12.2 Comparison of number of migrants from CEE Countries and all countries

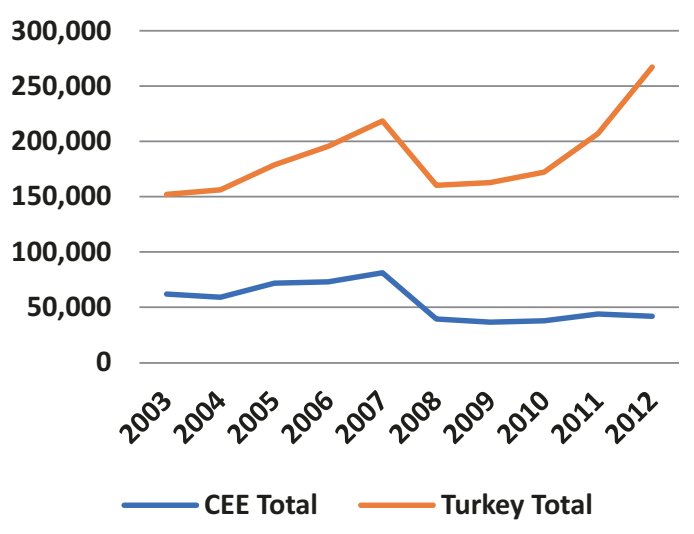

Chart 12.3 Change in CEE proportion at total migrants from 2003 to 2012

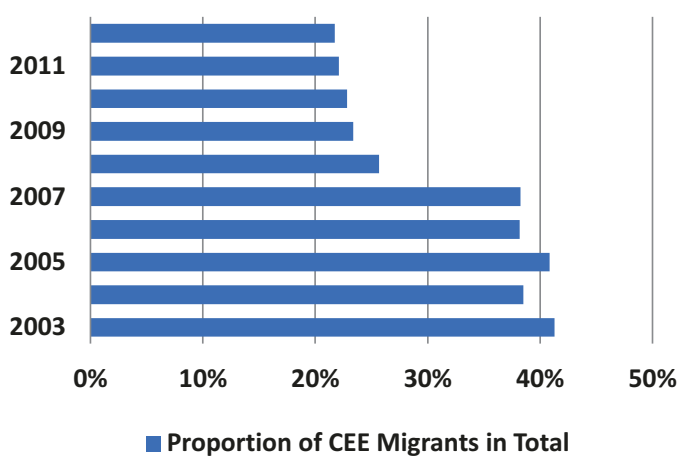

decline are the Eastern Enlargement of the EU in 2007 and more importantly, the faster increase of non-CEE migrants and the shrinking CEE proportion in the enlarging population of total migrants in Turkey. To illustrate, between 2008 and 2012, CEE population in Turkey increased by 2500 migrants, however, as the number of total regular migrants increased by 100,000, CEE nationals' proportion in the total migrants fell to its lowest levels since the Republic's foundation (Please see Chart 12.3).

Regarding the migration corridors with the CEE countries, the residence permit data from the Ministry of Interior demonstrates that Bulgaria has the steadiest migration corridor to Turkey while other migration corridors from Serbia and Montenegro, Ukraine, Romania and Moldova are also strongly established (Please see Figs 12.1 and 12.2). In the early 2000s, the number of regular migrants from Serbia and Montenegro, Ukraine, and Romania were lower compared to Bulgarians, but they still remained among the top three countries after Bulgaria. In more detail, statistics on residence permits that CEE migrants received between 2003 and 2012 highlight that the yearly residence permit approvals of Bulgarian migrants change between 55,000 and 15,000. Still following the second Eastern Enlargement of the EU in 2007, the number of regular Bulgarian migrants dropped by more than half. 
Fig. 12.1 The proportion of stocks of CEE migrants in 2003

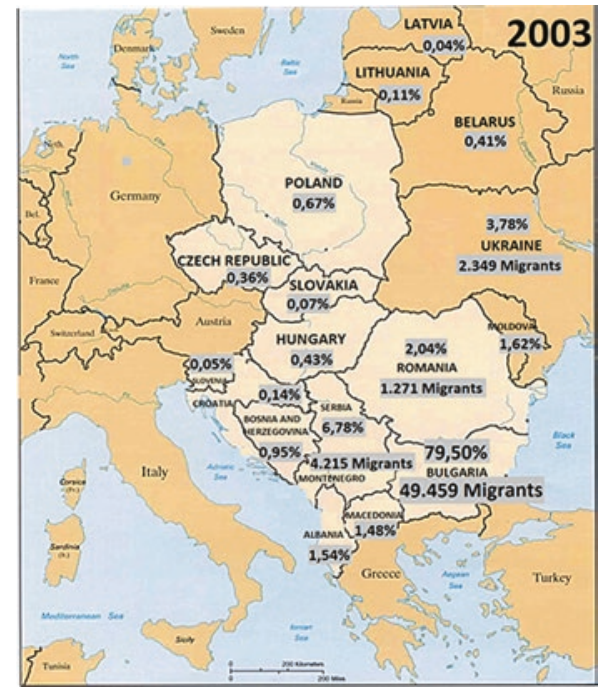

Fig. 12.2 The proportion of stocks of CEE migrants in 2008

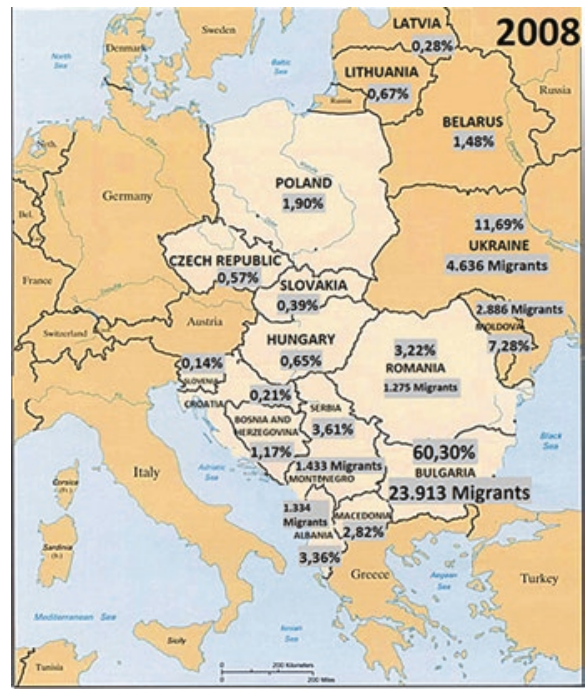

In the period between 2009 and 2012, strong migration corridors were also established with Romania and Poland, following Ukraine and Moldova. Overall, Bulgaria, Ukraine, Moldova, Romania, Macedonia, Poland, Albania, Belarus and Kosovo are crucial actors in the CEE regular migration scene in Turkey (Please see Table 12.1).

A more in-depth analysis of residence permits reveals the complex gender patterns of CEE migration. In spite of the widespread belief that CEE migrants are always women, Ministry of Interior's residence permit data revealed that male 


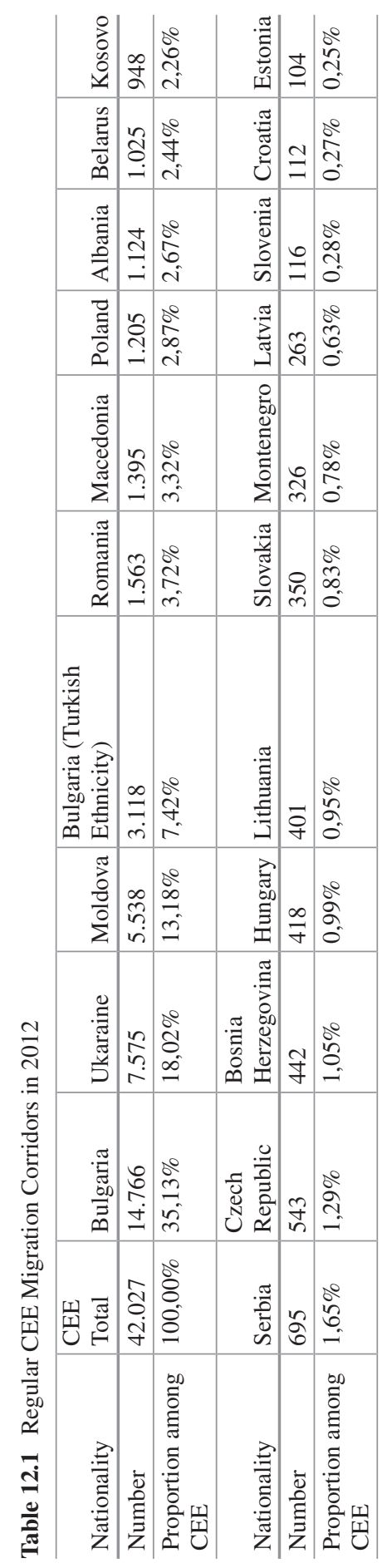


migrants reached as high as 75 percent of all regular CEE migrants in 2007. Still, even though male CEE migrants are usually the majority in the overall CEE community, an assessment of gender proportions based on origin country uncovers the fact that women from Latvia, Lithuania, Slovakia, Romania and Estonia are higher than men. Furthermore, although migrants from Moldova, Hungary, Poland and the Czech Republic display some mixed trends earlier; they also become female dominated after 2007. This contradiction between the overall male domination and the country specific female domination can be explained by the heavy weight of male migrants from Bulgaria. Since Bulgarian migrants have the largest share in the migration corridors between Turkey and the CEE, the male dominance of Bulgarian migrants has a balancing effect in terms of gender distribution against the female CEE migrants.

In the same data, residence permits based on education may provide some idea on CEE students excluding those whose residence is based on their parents' residence permits. Overall, approximately five percent of all CEE migrants have received residence permits based on education between 2003 and 2012. Along with this, CEE students represented 28 to 14 percent of all international students in a declining trend at the same period. In the year 2010, the proportion of non-CEE migrants in the international student community started increasing. To illustrate, in 2003, 6000 CEE migrants in this category constituted almost 28 percent of a total of 22,000 students. In 2012, however, the number of CEE migrants fell only to 4600, which now constituted close to 13 percent in a total of 35,000 international students in this category. Thus, similar to the residence permit patterns in general, the increase of non-CEE migrants and the slight fall in the CEE students decreased the CEE weight significantly. Regarding the migration corridors, students from Bulgaria, Albania, ex-Yugoslavia including migrants from Kosovo, Serbia and Montenegro and Macedonia have established strong student migration corridor with Turkey.

Next, employment statistics received from the Ministry of Interior demonstrate that CEE migrants, who hold work permits, changing between 2.700 to 5.300, represent 13 to 19 percent of all migrants who were issued work permits in the period between 2003 and 2012. In this population, although the number of female CEE migrants usually fell behind the number of males until 2008, their numbers were close to equal in 2009 and in 2012, female migrants almost doubled the male workers. Regarding origin countries, the largest labor migration corridor is established with Ukraine, followed by strong migration corridors with Bulgaria and Romania, and after 2008, with Moldova and Poland. Here, similar to the patterns of CEE student migration, CEE migrants with work permits only increased approximately by 2000 while total work permits increased from 17,000 to 33,000 from 2009 to 2012, creating a massive fall in the CEE proportion. Here, the proportion of increase in the CEE migrant community is higher than the total increase. Still, in the rapid expansion of the Turkish labor market, the CEE proportion remained limited.

Concerning citizenship acquisitions, as the final data available in relation to regular migrants, CEE migrants constitute over 40 percent of migrants who acquired citizenship in the period between 1989 and 2012. More specifically, in a total of 
more than 250,000 citizenship acquisitions, approximately 120,000 citizenship acquisitions belonged to CEE nationals. Among the citizenship acquisitions of this group, Bulgarians constitute approximately 90 percent of all citizenship acquisitions with slightly more than 104,000 citizens, followed by Romanians, Moldovans, Macedonians and Ukrainians. Furthermore, as the most common route to acquire citizenship is through ethnic kinship, citizenship through marriage with a Turkish citizen represents roughly ten percent of all acquisitions. Still, citizenship through marriage is widespread among Belarussians, Moldovans and Polish. However, the available citizenship statistics do not disclose more detailed information concerning the grounds migrants acquired their Turkish citizenship.

\subsubsection{Irregular CEE Migration into Turkey}

The data available on irregular migration in Turkey is limited to the number of apprehensions and human trafficking provided by the Ministry of Interior Affairs. To begin with, 30 percent of a total of 50,000 apprehensions based on irregular migration in 2003 were of CEE migrants. Almost half of these irregular CEE migrants were Moldovans, followed by Romanians (18 percent), Ukrainians (13 percent) and Bulgarians (six percent) in smaller numbers. With the Eastern Enlargements of the EU in 2004 and 2007, CEE apprehensions decreased to 7000 in 2005 and to 3000 in 2008 and the apprehension of CEE irregular migrants is on a general decline. Next, human trafficking statistics demonstrate that only a total of 1145 cases came to the attention of state authorities between the years 2004 and 2010. Accordingly, 29 percent of all human trafficking incidents included a CEE national with 288 Moldovans, 27 Romanians and 11 Bulgarians in this population. Based on these statistics, CEE human trafficking cases display a decreasing pattern in Turkey. However, neither the numbers on irregular migration nor human trafficking are realistic for several reasons. Due to its geographical situation, growing economy and widespread informal labor, Turkey is a major country of transit and destination for irregular migration flows. As these factors are coupled with the current mass migration of Syrians, the numbers of irregular migrants are visibly and substantially higher than the available statistics.

Following this background on regular and irregular CEE migration based on official statistics at the national level, an assessment of the diverse range of CEE migrant profiles in the specific urban regions Edirne and Istanbul will shed more light on this migration type. Due to the lack of statistics on the local level, the source of information here is limited to the non-governmental organizations, state authorities and consulate officials. Firstly, in Edirne, permanent, high-skilled CEE migrants settled during the Cold War period and CEE university students are the two most apparent migrant types. Additionally, while Edirne does not commonly host irregular CEE migrants, this province is associated with irregular migrants who aim to cross the borders to reach Europe. Therefore, it should be noted that CEE migration in Edirne is frequently overshadowed by tragic migrant deaths. Secondly, in Istanbul, 
CEE migration is visible in many categories, including the high skilled migration of professionals, low skilled migration of domestic workers with both regular and irregular status, marriage migration, increasing numbers of student migration and finally, trafficked persons - even though the official numbers from CEE seem to be decreasing. Thus, the assessment of these two different CEE migration contexts offers a thorough and integral view of CEE migration in Turkey.

\subsection{CEE Migration in Edirne and Istanbul}

The two research areas under study in this book chapter, Edirne and Istanbul, constitute diverse settings for CEE migration in linkage to their distinct migration histories. Before highlighting the differences in the implications of CEE migration in these urban regions, however, it should be noted that migrants' experiences of integration in Turkey differ based on three main factors. First, CEE migrants from countries with long-established migration corridors usually join the regular labor force without much difficulty by using their connections with permanent migrants from their origin country. Second, the duration of residence in Turkey also has a direct effect on CEE migrants' integration level. In this study, residence in Turkey is categorized into four terms: Temporary, mid-term and permanent stayers and circular migrants. ${ }^{6}$ The third factor influencing the level of integration is the migrant's category. While no statistics are available on the specific migrant categories, knowledge workers, entrepreneurs, manual workers, domestic workers, sex workers and trafficked persons, students and non-working spouses are known to be common migrant categories in Turkey and as will be discussed below, some migrant categories have less advantaged experiences of migration. Against this background, more in-depth information on the urban regions will shed light on the implications of CEE migration in Edirne and Istanbul.

\subsubsection{CEE Migration in Edirne}

To begin with, the largest community among the permanent migrant population in Edirne is the ethnically Turkish Bulgarians settled in this area during the Cold War period. Welcoming this migration wave on the grounds of ethnic kinship, Turkish state built migrant neighborhoods, namely Binevler area which today is the most upscale neighborhood in Edirne. Most members of this ethnic Turkish community received dual citizenship when Bulgaria's accession to Europe became evident and currently, enjoy a transnational life style with high mobility across the border and continuing connections to Bulgaria. Moreover, this permanent migrant population

\footnotetext{
${ }^{6}$ Temporary stay is shorter than one year, mid-term is between one and five years, permanent stay is five years or longer and circular stay is repeated migration.
} 
is well integrated and perceived by the public as well educated, high skilled and hardworking. Permanent CEE migrants, according to the general opinion, have well employed the benefits of multiple citizenship and state services that allowed them easy access to housing and employment. Today, permanent and regular CEE migrants from Bulgaria, Albania, Bosnia Herzegovina, Hungary, Kosovo, Macedonia, Moldova, Romania and Ukraine form Edirne's highest socio-economic group and belong to the migrant categories of knowledge workers, entrepreneurs and less often, manual workers. Concurrently, these high CEE migration rates in the urban region generate the migrant category of non-working spouses and children.

Aside from the permanent CEE migrants, Edirne receives a large-scale student migration from Kosovo, Serbia, Montenegro, Croatia and Macedonia in connection to the University of Trakya, which has established the well-known Balkan Research Center and the Department of Balkan Languages and Translation. Aiming to draw students from Balkans, University of Trakya is shaping the student migration patterns in the province. To illustrate, CEE students enrolled in the university in 2013 are approximately 47 percent of the total foreign student population in the province. The largest CEE student communities are from Kosovo with 287 students, Bulgaria with 215 students, Macedonia with 103 students and Albania with 33 students, which are mostly gender balanced groups. Membership of student solidarity organizations based on nationality is very common among this well integrated population. It should be noted here that even though student migration can be categorized under temporary or mid-term migration, CEE students in Edirne often have longterm plans to reside in Turkey permanently after graduation. Unfortunately, no specific data is available on the number and backgrounds of the students who actually realize this plan.

\subsubsection{CEE Migration in Istanbul}

The second research area under study is Istanbul, known as Turkey's migration hub hosting a diverse range of CEE migrants. To begin with, since the 2000s, female domestic migrants, mostly caretakers from the CEE region have replaced the internal migrants from less developed regions in the care sector. In this category, irregular Moldovan and Bulgarian women are assumed to be the most numerous among the CEE migrants (Suter 2008). ${ }^{7}$ Recent legal amendments concerning domestic labor have facilitated the acquisition of residence and work permits. However, employers' unwillingness to pay the high social security fees for the migrants, the lack of migrants' documents and migrants' fear of deportation once noticed by the authorities persist the widespread irregularity. As a high number of female migrants spend long periods in Turkey despite their irregular status, the line between temporary and permanent migration for this migrant type is blurred. Moreover,

\footnotetext{
${ }^{7}$ Suter, B. (2008) 'The different perception of migration from Eastern Europe to Turkey: The case of Moldovan and Bulgarian domestic workers.'
} 
excluding the ethnically Turkish Bulgarians, the common prejudice that CEE women engage in prostitution creates even more adversity for irregular female CEE migrants in Turkey.

A second type of CEE migrant category in Istanbul is the high skilled migrants and entrepreneurs who consider Istanbul as an attractive destination to live and work due to the historic ties between Turkey and CEE. Apart from the CEE professionals employed in the highly competitive job market, small-scale Hungarian and Czech entrepreneurship through Turkish partnership-as required by the Turkish business laws, is common. As frequent among the Czech community, high skilled migrants often re-unite with their families in Istanbul. While most migrants in this group are career oriented, temporary stayers, some CEE migrants engaged in international trade can also be categorized as circular migrants.

Thirdly, in linkage to this last point, family unification and marriage migration are common patterns of CEE migration in Istanbul. A great majority of Hungarian and Czech migrants in Istanbul are women married to Turkish citizens. Furthermore, the number of dual citizens with Hungary is on the rise after Hungary's facilitation of dual citizenship for those married to citizens of Hungary as well as their children. ${ }^{8}$ Therefore, although this group constitutes mostly of permanent stayers, those with dual citizenship often enjoy the trans-border life style and can be categorized as circular migrants.

A fourth type of frequent CEE migration in this urban region is student migration. However, the weight of exchange students involved in Erasmus, bilateral student exchange agreements, and other EU scheme characterizes CEE student migration in Istanbul more temporary compared to Edirne. Finally, a migration type that still remains partially in dark is human trafficking. The highest populations of human trafficking cases, according to the IOM, originate from Moldova and the Ukraine and involve women aged between 18 and 24 years. ${ }^{9}$ Accordingly, Istanbul is a main port of human trafficking where women are brought into Turkey "legally" under the cover of tourist visas valid for 3 or 6 months. ${ }^{10}$ However, the lack of data on this migrant category does not allow making further assumptions on these migrants' duration of residence.

\subsection{Diversification of CEE Migrants: Temporality and Socio-Economic Status}

Overall, temporality and socio-economic status seem be two key points of diversification for the major types of CEE migrants in Turkey. To illustrate the diversification based on temporality, first, the permanency of the most settled community of

\footnotetext{
${ }^{8}$ The information specific to Hungarian and Czech migrants is based on interviews with the Hungarian and Chech Consulates.

${ }^{9} \mathrm{http} / / /$ www.turkey.iom.int/pa2.htm accessed on November 10, 2015

${ }^{10} \mathrm{http}: / /$ www.turkey.iom.int/pa2.htm accessed on November 10, 2015
} 
Bulgarians becomes questionable as they spend longer periods in Bulgaria compared to before Bulgaria's EU accession. Second, student migration and short-term exchange programs are being encouraged at a greater extent, which increases the weight of temporary stays among the CEE migration. Third, as qualitative findings demonstrate, professional migrants in Istanbul mostly regard employment in Istanbul as a temporary life-plan rather than seeing Turkey as their home. Finally, other types of CEE migration move towards more permanent migration. The increasing family unification and marriage migration patterns, migrants in the domestic sector who reside permanently despite their irregularity, and finally, CEE students enrolled in universities who often make long-term plans to reside in Turkey illustrate this tendency towards permanent residence. Thus, temporality is an element that sheds light on the diversity of CEE migrants in Turkey.

Another key point in the diversification of CEE migration is migrants' socioeconomic status, which seems closely related with their migration type. In Edirne, first, ethnic Turks from Bulgaria are considered to enjoy higher living standards than the general population. As this community brought with them a certain level of social capital and artisanship when they settled in Edirne during the Cold War period, in time, they also acquired a socio-economically higher status. Second, CEE students generally seem in conformity with the university student profile in Edirne. Hence, even though the distinction between high/low socio-economic statuses may not always be crystal clear, CEE migrants in Edirne have either higher or similar socio-economic status compared to the general population. In Istanbul, the socioeconomic status of CEE migrants is more diverse compared to Edirne. On the one hand, low skilled migrants employed in the domestic sector as caretakers, whether irregular or regular, generally earn less compared to Turks working in the same sector. On the other hand, high skilled migrants, such as Hungarians and Czechs regularly employed in the job market or those residing in Istanbul either as spouses seem to present a socio-economically high profile. ${ }^{11}$ In parallel with the findings in Edirne, CEE students in Istanbul do not display a great variance from the general university student profile in terms of socio-economic status. Thus, along with temporality, the different levels of socio-economic status also prove the diversity of CEE migrant population.

\subsection{Urban Implications of CEE Migration}

Assessing the implications of CEE migration is a challenging task. First, the presence of a high number of non-CEE migrants overshadows the specific implications of CEE migration. Second, the expertise on CEE migration is immature in Turkey. In this regard, the fact that solely a handful of public institutions or non-governmental organizations only partially, concentrate on the topics concerning migration results

\footnotetext{
${ }^{11}$ The information specific to Hungarian and Czech migrants is based on interviews with the Hungarian and Chech Consulates.
} 
in a major data constraint. Third, the implications on the domains concerning less heated issues such as social and political participation, housing and neighborhood consequences or education and language are outweighed by hotly debated domains of labor and registration of migrants in general. Within this frame, to shed light on the influences of CEE migration in Edirne and Istanbul, CEE specific data was collected through online surveys, expert interviews and a focus group organized with the participation of migration experts, stakeholders including public offices and NGOs. Based on this data, the following part will focus on five domains where CEE implications are visible: (1) labor market, (2) housing and neighborhood consequences, (3) registration, (4) social security and welfare, health, societal and political participation and finally, (5) education and language.

\subsubsection{Urban Implications of CEE Migration in the Case of Edirne}

A better comprehension of CEE implications requires a quick glance at Edirne's general character. This urban region offers only a limited job market due to its constrained industrial base and thus, most residents join the labor force as public servants, agricultural workers or entrepreneurs. CEE migrants enliven the small local economy and broaden the narrow employment profile by entering the job market as knowledge workers and entrepreneurs. In this context, manual workers are more infrequent than knowledge workers and entrepreneurs because the Roma population or the internal migrants from Eastern Turkey often take the low number of disqualified jobs in Edirne's labor market.

In more detail, to begin with the knowledge workers, time of migration is a key determinant of the challenge level in the labor market. To illustrate, permanent CEE migrants employed as knowledge workers experience fewer problems in comparison to newcomers due to their established networks, market experience and accredited diplomas. Today, qualified newcomer migrants face major challenges concerning diploma accreditation considering that many workplaces refuse to make preliminary contracts with migrants before their diplomas are formally recognized and in a vicious cycle, that Turkish authorities start the accreditation only once they receive a migrant's preliminary work contract.

Second, entrepreneurs who deal with trans-border trade or own small businesses are a frequent migrant category in Edirne. Following their mass migration, ethnically Turkish Bulgarians were provided business credits and benefitted from their bilingualism, which is a high asset due to Edirne's proximity with Bulgaria. Many CEE entrepreneurs join Edirne's labor market as entrepreneurs in small businesses ranging from restaurant management and the beauty sector to goldsmith. Overall, labor implications of CEE migration are widely considered as positive as CEE migrants have vitalized the economy and the labor market in the province. 
Concerning housing and neighborhood consequences of CEE migration, permanent CEE migrants reside in the most expensive Binevler region state-built for the ethnic Turks from Bulgaria. Utilizing the facilitated mortgage options offered by the state, members of this community could afford buying housing and even renting their second housing to newcomers in the early 2000s. In-depth interviews with stakeholders demonstrate, however, that jealousy arose among the low socio-economic groups in Edirne living in Edirne's poorest neighborhoods with bad housing conditions. Meanwhile, in-depth interviews also reveal CEE migrants' skepticism against the internal migrants from Eastern Turkey. Aside from the positive experiences of permanent migrants, mid-term CEE students often share housing with crowded groups as rents have increased with the incoming student population. In response to this difficulty, several CEE investors started buying houses to transform into student accommodation and new public dormitories are being built for foreign students. Concerning neighborhood consequences, public's perception of students is generally positive and the students' preference for Edirne is considered as a source of pride for the locals.

Concerning registration, at a first glance, most permanent CEE migrants employed as knowledge workers, entrepreneurs and manual workers in Edirne are registered as citizens and thus, face no problems in this domain. In terms of labor registration, Edirne's Chamber of Commerce introduced an electronic system for business registration to facilitate the process to encourage entrepreneurs and investors. Dissimilar to these positive experiences of CEE migrants, registration for students involves a long bureaucratic procedure between the Ministry of Education, their university and the police department. Once the Turkish Ministry of Education recognizes students' high school diploma and the university receives their recognition document, students will apply to the police department, which then issues a residence permit. Thus, being accepted to a Turkish University does not always guarantee registration. This registration duty has been transferred from the Foreigners' Police to the provincial organization of Directorate General of Migration Management in May 2015, however, the performance of the new registration model is not yet clear. Finally, concerning the migrant category of non-working spouses, CEE migrants in mixed marriages usually apply for Turkish citizenship, which takes between six months and three years, but is often a smoothly working process.

Regarding the domain of societal participation, permanent CEE migrants are quite visible and well represented by numerous migrant NGO's. In-depth interviews reveal that politically, CEE migrants from ex-socialist countries often avoid the leftwing and instead, feel closer to migrant solidarity organizations advocating their national roots, e.g., "Organization of Turks from Bulgaria's Kardzhali" and "Turks from Bulgaria's Razgrad". Likewise, CEE students are active in organizations such as the Kosovan Students Club or Bosnian Students Club, which have networking activities with other CEE student organizations and migrant business people that sometimes financially support CEE students in Edirne. Apart from this, economic 
vulnerability sometimes drives CEE students to membership in Islamic organizations for scholarships, as widespread in Turkey with both Turkish and non-Turkish students.

Next, within the frame of reciprocity agreements and high public investments in Edirne's health sector, the domain of social security and health services is generally a settled area for permanent CEE migrants. For students with no scholarships, however, expensive health services and high social security fees are a major disadvantage. Aside from this, the well-known hospital under the University of Trakya has started health tourism by attracting high numbers of patients from Bulgaria, Romania and Greece.

The implications of CEE migration in education and language vary mostly in connection with duration of residence in Edirne. To begin with, the education level of the permanent CEE community is generally high and language does not seem to be a challenge for this migrant population as they mostly arrived in the Cold War period. However, except from the Turkish-speaking students from Kosovo, Gagauzia or Macedonia, newcomer students experience language difficulties as they are expected to follow classes in Turkish. Overall, language and language education, especially of Bulgarian and Greek, play a major role in Edirne's economy. For instance, CEE knowledge workers or entrepreneurs, who sometimes experience language problems in business negotiations or concerning legal contracts, employ bilingual CEE migrants as translators. At the same time, Bulgarian entrepreneurs often attend Turkish courses in Bulgaria to trade with Edirne. In this context, Turkish and Bulgarian governments agreed to facilitate the establishment of language institutions. Apart from the issue of Turkish, in-depth interviews demonstrate the concern of the Ukrainian community over the preservation of their language and culture as the second and third generations of Ukrainians in Edirne are now fully integrated into Turkey.

\subsubsection{Urban Implications of CEE Migration in the Case of Istanbul}

Implications of CEE migration in Istanbul are currently overshadowed by the Syrian mass migration. As the unforeseen, intensive flows of Syrians and their highly visible presence in Istanbul is a much-heated topic both with the public and state authorities, "migrant" has recently become synonym to "Syrian" in Istanbul. The arrival of unexpectedly high numbers of Syrian migrants into Istanbul has caused a sudden appearance and surfacing of extreme xenophobia, and a deteriorating public image of migrants and refugees. Due to the scapegoating against the Syrians and migrants in general, most locals typically adopt a totally negative stance against the presence of migrants in Istanbul, or for some of them, their negativity towards the Syrian migrants pushes them to consider the CEE migrants as "better migrants". 
In spite of this adversity, as a huge center of trade and industry, Istanbul attracts migrants of various backgrounds from around the globe including knowledge workers, entrepreneurs and manual workers of both regular and irregular status. Coupled with the widespread informal labor in most labor areas, the lack of social policies concerning child and elderly care services also opens a vast employment area for domestic workers. Finally, both short and long-term international students are attracted to nine public and 40 private universities in Istanbul.

In this frame, Istanbul's vast labor market consists of various CEE migrant categories ranging from permanent knowledge workers and entrepreneurs from Albania, Bosnia Herzegovina, Bulgaria, Kosovo, Macedonia, Romania and Ukraine, manual workers from Moldova, Belarus, Croatia, Montenegro, Poland and Serbia, domestic workers from Moldova and Ukraine and in some cases, CEE students involved in the labor force irregularly. Until 2008, CEE sex workers and trafficked persons, mostly consisting of women from Romania and Moldova were the largest migrant community among all sex workers and trafficked persons in Istanbul. Since then, their numbers have decreased and fallen behind the Central Asian migrants. Information gathered from the in-depth interviews and a focus group study provides more detailed information on the implications of labor market in Istanbul.

Accordingly, the main challenge for high skilled CEE professionals is Istanbul's competitive labor market, which includes both local and international migrants and reduces the likelihood of finding permanent employment. As the second category, CEE entrepreneurs in Istanbul mostly focus on suitcase trade through which they sell Turkish goods and products in their home country and also transport goods to the families of irregular CEE migrants in their home countries. Due to the high demand for Turkish commodities in Bulgaria, Macedonia, Bosnia Herzegovina, Kosovo and Romania and the constant need of irregular migrants to send goods to their home countries, this entrepreneurship is very common, especially in the migrant populated areas.

Apart from these two migrant categories, the enormous labor market also hosts foreign manual workers. Although the Syrian, Afghan and Iraqi irregular migrants take the current disqualified jobs, Bulgarian migrants worked in the temporary, lowskilled jobs as irregular migrants in the 1990s. Today, many irregular CEE manual workers are employed in the textile sector; however, their irregularity leads to lack of information on their numbers, market conditions and profile. Here, it should be highlighted that there is no consensus on how the irregular labor force should be evaluated in Turkey. According to the one side of the debate, irregular workers should be registered to end their vulnerability against employers and to standardize better working and living conditions while according to the other side of the debate, state's registration or irregular migrants may first, increase unemployment and second, generate the risk of deportation for the irregular migrants.

Another migrant type that is partially in dark due to irregularity is the domestic workers most of whom are female CEE migrants who enter with tourist visa and overstay. Employed as caretakers or cleaners, most migrants in this category live in their employers' house to save enough to send remittances. Subject to employers 
some of whom seize migrants' passports, irregular domestic migrants often earn less than Turkish women employed in this sector. Similarly, CEE students also may become part of the irregular labor force in Istanbul due to the low number of scholarships and the insufficiency of existing scholarships' allowances. As the work hours allowed for foreign students is 24 hours per week and this right is not valid until a student completes the first academic year, many CEE students irregularly join the labor force in the areas of tourism and service sector as most speak Turkish, Russian and English. However, due to their irregularity, they are vulnerable against employers and they encounter the risk of losing scholarships.

In the domain of housing and neighborhood consequences, CEE migrants are found dispersed across Istanbul where their experiences differ significantly based on their residence status. An analysis of the heavily migrant-populated Beyoğlu, Fatih and Zeytinburnu districts demonstrates this dissimilarity. For instance, regular CEE migrants from Albania, Bosnia Herzegovina, Bulgaria, Macedonia and Romania live in the middle class Telsiz neighborhood of Zeytinburnu which is home to a high number of well integrated and permanent CEE entrepreneurs and manual workers with good reputations as talented, disciplined and trustworthy migrants.

Irregular CEE migrants, however, are found in the poorer Tarlabaşı in Beyoğlu and Aksaray in Fatih all of which are also home to manual workers from Syria, Iraq, Uzbekistan and African Countries. Due to high rents for low quality housing, irregular CEE migrants in these areas often rent single rooms alone or share flats with other CEE migrants employed in textile shops that sell cheap leather products to foreigners in Aksaray. In the past, Aksaray was associated with CEE sex workers who now seem dispersed in the urban region. Still, it is common to label all CEE women in these neighborhoods as Natashas that is used as a synonym for sex workers from the Former Soviet Union and Eastern Europe. As another negative example concerning neighborhood consequences, Georgian manual workers in Aksaray are claimed to often dispute with the local residents and seem to be generally disliked because they are believed to engage in theft. In contrast, in the heavily migrant populated district of Fatih, CEE migrants seem to be more accepted compared to African and Syrian migrants. Apart from these, most Ukrainian and Moldovan domestic workers reside in their workplaces in Istanbul's most expensive neighbourhoods. While they face the risk of exploitation due to their irregularity, they live in better housing conditions compared to most irregular CEE migrants.

Regarding registration, besides the widespread irregularity, CEE knowledge workers must undergo an exhausting bureaucratic process during the recognition or verification of their documents due to the phenomenon of purchased diplomas in their countries. Because most companies require a work permit from a job candidate and state authorities frequently refuse to issue a work permit if a foreigner does not have a job contract, knowledge workers' have difficulties in registration. Concerning the other categories, entrepreneurs are encouraged to make their monthly wage payments to their manual workers via Turkish banks as a means for the Ministry of Finance to monitor the registration of foreign workers and repress irregular employment. Irregular migrants, whether manual workers or female domestic workers, 
even if they wish to be registered, find it risky to approach the police authorities due to the fear of deportation and prefer to remain invisible. For the category of sex workers and trafficked persons from CEE countries, the domain of registration appears to be more problematic compared to the other migrant categories. In some cases, a very thin line separates domestic workers from sex workers or trafficked persons and the state authorities may deport migrant women without considering the possibility of human trafficking. Unlike most other CEE migrant categories, non-working spouses, typically women married to Turkish citizens; do not appear to encounter registration difficulties as they obtain citizenship through their marriage.

The domains of societal and political participation are mostly dependent on migrants' residence status. Regular and permanent CEE migrants have high rates of membership in migration organizations and are well integrated in their communities. Furthermore, their political ideologies appear to be of lesser importance compared to their group loyalty. Thus, when a community member joins a political party, others often support this party even if they do not share their political views. For the CEE students, despite their high number, the number of student organizations is lower than in Edirne in spite of the high number of CEE migrants. However, unlike Edirne where each community has its own student organization, NGO's in Istanbul, such as the Balkan Dialogue Groups bring together students from various Balkan countries. Apart from these, irregular migrants, even though they do not have formal membership in migrant NGO's, are very well connected in their communities. However, this connectedness is mostly related to sharing information on registration and security or the available job opportunities. Thus, political participation is not a concern for irregular migrants. Likewise, non-working spouses do not seem to be interested in political participation and instead, they have migrant solidarity organizations for their own community, e.g. Latvian wives.

Concerning the educational backgrounds and language proficiency, the heterogeneity of CEE migrants in Istanbul does not easily permit generalizations. Firstly, the regular and permanent CEE migrants settled in Istanbul during the Cold War period are generally high skilled, well educated and as they are fully integrated, they speak Turkish well. The language domain for the well-educated CEE knowledge workers seems primarily to depend on their employment area. Among the permanent or short-term CEE employees of international firms and universities, the motivation to learn Turkish is very low as English is often a valid working language in these circles. In similar, CEE students are mostly enrolled in short term university exchange programs for which they may not need to learn Turkish. As most universities offer programs in English, Turkish is not an obligatory language for university studies. While the entrepreneurs' education level in Istanbul is not well known, learning Turkish seems to be more crucial for this category. Likewise, less educated CEE manual workers, whether regular or irregular, often need to learn basic Turkish to get on by every day. However, there are no state efforts for the integration of foreign manual workers into the education system or provision of 
language courses for permanent or short-term migrants. In the category of nonworking spouses and children, no information is available regarding the implications of spouses concerning education and language. However, children born in Turkey have the right to attend public schools, regardless of their residence status. For the domestic workers and sex workers and trafficked persons, migrant profiles seem to vary greatly but no concrete data exists on the educational backgrounds. However, in-depth interviews reveal that learning Turkish increases sex workers' chances for working as domestic workers or manual workers.

\subsection{Conclusion and Discussion}

The heart of the distinctions between the implications of CEE migration in Edirne and Istanbul is linked to their dissimilar characters. On the one hand, Edirne is a small, strictly controlled border city with a limited industrial base and mostly permanent migration. On the other hand, Istanbul is a large, less controlled province that is home to extensive flows of short and long-term internal and international migrants. This context shapes the implications of CEE migration in the domains of labor market, housing, neighborhood consequences, registration, social security, societal and political participation, education and language.

To outline the basic points, CEE migrant types in Edirne and Istanbul show variances. In Edirne, the most visible CEE migrant categories are knowledge workers, entrepreneurs and students well integrated into Edirne's urban fabric and is known to have enlivened the province through their education and skills. In Istanbul, the most frequent CEE migrant categories are knowledge workers, entrepreneurs, manual and domestic workers. However, the heterogeneous migrant profile does not easily permit general statements. In addition, the category of CEE sex workers and trafficked persons is known to exist even though little is known on this migration type. In both urban areas, knowledge workers, entrepreneurs and students receive most of the attention and overshadow the remaining categories of manual workers, non-working spouses and in the case of Istanbul, domestic workers, sex workers and trafficked persons.

Based on the stakeholder survey results, the most frequent trend in both urban regions is permanent CEE migration followed by circular migration. In the case of Edirne, the presence of dual citizens coupled with the strong role of trade with the CEE and in Istanbul, the substantial number of irregular domestic workers may lead to this weight of circular migration. Still, Istanbul holds more mid-term and shortterm stayers compared to Edirne. Additionally, unlike Edirne, Istanbul is home to an irregular CEE population. Here, irregularity of long-term migrants is also possible, e.g. irregular domestic workers. Moreover, given the changing nature of migration systems, the established patterns also evolve. Even in the case of earlier migrations, where CEE migrants are considered as permanent migrants, their permanency may 
be questionable. For instance, with the accession of Bulgaria into the EU, many ethnically Turkish Bulgarians applied for Bulgarian citizenship to become dual citizens and have begun to lead more transnational lives. In this mode, their permanent migration becomes more transnational. Hence, as the old migration patterns are evolving, and new patterns are emerging, the task of mapping CEE migration on temporality and socio-economic status is becoming harder. Thus, in cases similar to the highly diverse CEE migration in Turkey, these two elements typically used to categorize international migrants may be insufficient.

In summary, against this background, in the domain of labor market, CEE migrants in Edirne appear to be generally more privileged in comparison to Istanbul as they are strongly supported by the local authorities, admired for their hard-work and high skills. In Istanbul, a much higher level of competition and the availability of both local and foreign knowledge workers complicate the labor market. Likewise, in the domain of housing, CEE migrants in Edirne appear to mostly have better standards of housing than those in Istanbul. Concerning neighborhood consequences, dissimilar to Edirne several CEE migrant types in Istanbul face discrimination (e.g. irregular female migrants). Regarding registration, majority of CEE migrants in Edirne have obtained citizenship while irregularity is frequent in Istanbul. The consequences of irregularity are the inability to benefit from the social security and welfare systems and difficulties in access to health services. Regarding the domain of societal and political participation, regular CEE migrants in both urban areas are represented by numerous migrant organizations except the less visible categories of domestic workers, sex workers and trafficked people in Edirne. The implications concerning education and language seem to vary mostly in connection with the migrant categories and their duration of residence. Still, education profiles are more heterogeneous in Istanbul compared to Edirne and language seems to be less required to live in Istanbul where learning Turkish is more widespread in Edirne due to the weight or permanent migrants.

Overall, research on migration corridors, migrant categories and urban implications of CEE migration is challenging due to the unavailability of basic statistics, lack of expertise, stakeholders' disinterest on some migrant categories and domains, invisibility of irregular CEE migrants and the dominance of Syrian mass migration in the public and state discourse. Still, the parallel and contrasting features of implications based on the existing information demonstrates how the dissimilar migration contexts shaped the outcomes for the CEE migrants and reflected on specific domains ranging from labor market to education. Thus, the diversity in the CEE migrant profiles in the two urban regions is remarkable.

As Turkey currently receives an increasing number of migrants with diverse backgrounds, the management of urban consequences of temporary and more permanent forms of migration is of key importance. However, in spite of the immigration since the 1980's policy makers only recently accepted that Turkey is a migrant 
receiving country. The fact that the first comprehensive legal instrument on managing international migration, the Law No. 6458 of Foreigners and International Protection, endorsed in May 2015, illustrates how international migration to Turkey has become a policy concern only very recently. Thus, Turkey is going through a time of major change in its migration management.

Due to this policy vacuum on international migration, the Turkish legal framework in relation to migrants typically consists of state centered legal orders fragmented into ad hoc, jurisdictionally complex and sometimes inconsistent arrangements. In this setting, the Law on Foreigners and International Protection aims to embrace a comprehensive approach to migration management, eliminate the excessive bureaucracy of registration and establish procedural standards in every migration related domain. In this direction, following the endorsement of the law, the Directorate of Migration Management was established under the Ministry of Interior in 2015. Seemingly contradictory to the aim of reducing the bureaucracy, another state institution, the Prime Ministry Head Advisory for Migration and Humanitarian Aid has entered the scene in 2016 as a new stakeholder in migration management with the aim of establishing a network and coordination between state institutions on the management of the Syrian mass migration. Moreover, the first days of 2016 also witnessed the enforcement of new regulations regarding the work permits of foreign nationals under temporary protection, tailored specifically for the Syrian migrants in Turkey. While the enforcement of regulations facilitating employment for Syrians may raise eyebrows due to the unfairness against non-Syrian migrants, it is not yet possible to imagine their reflections on the future of migrants in Turkey. The key question here is whether the expansion of Syrian migrants' rights will have positive repercussions on other migrants; however, it is still too early to make any predictions on the subject.

Furthermore, these progresses do not yet bring an end to the debates surrounding the governance approaches to migration. Despite the progress, the state-centered hierarchical order, the top-down understanding towards policy making and a security based approach still dominate the migration governance. The sharp shift from neglect to integration of millions of migrants requires an enormous change of mindset. The main fault line in this critical debate runs between those who believe migrants should be offered easy access to labor and extensive rights of social security and those who fear this would create an inequality between migrants and Turkish citizens who do not enjoy a high level of social security, especially if they are employed informally. This fault line, appearing in relation to almost all policy areas, runs deep because it is linked to most basic ideas on immigration, integration and naturalization. The common suggestion shared by all sides, however, is the need for more state focus on migrants' integration and the necessity to create a positive public opinion of migrants to facilitate this process. 


\section{References}

Çağatay, S. (2007). Race, Assimilation and Kemalism: Turkish Nationalism and the Minorities in the 1930s. Middle Eastern Studies, 40(3), 86-101.

Kirişci, K. (2006). Disaggregating Turkish citizenship and immigration practices. Middle Eastern Studies, 36(3), 1-22.

Parla, A. (2003). Marking time along the Bulgarian-Turkish border. Ethnography, 4, 561-565.

Parla, A. (2006). Longing, belonging and locations of homeland among Turkish immigrants from Bulgaria. Southeast European and Black Sea Studies, 6(4), 543-557.

Suter, B. (2008) The different perception of migration from Eastern Europe to Turkey: The case of Moldovan and Bulgarian domestic workers.

Websites: IOM Turkey: http://www.turkey.iom.int/pa2.htm

Open Access This chapter is licensed under the terms of the Creative Commons Attribution 4.0 International License (http://creativecommons.org/licenses/by/4.0/), which permits use, sharing, adaptation, distribution and reproduction in any medium or format, as long as you give appropriate credit to the original author(s) and the source, provide a link to the Creative Commons license and indicate if changes were made.

The images or other third party material in this chapter are included in the chapter's Creative Commons license, unless indicated otherwise in a credit line to the material. If material is not included in the chapter's Creative Commons license and your intended use is not permitted by statutory regulation or exceeds the permitted use, you will need to obtain permission directly from the copyright holder. 